\title{
Clonal structure of Ceratocystis manginecans populations from mango wilt disease in Oman and Pakistan
}

\author{
A. O. Al Adawi ' I. Barnes* · I. A. Khan · M. L. Deadman · B. D. Wingfield · M. J. \\ Wingfield
}

\begin{abstract}
A. O. Al Adawi * *I. Barnes (corresponding author) B. D. Wingfield · M. J. Wingfield
Department of Genetics, Forestry and Agricultural Biotechnology Institute (FABI), University of Pretoria, Pretoria 0002, South Africa

e-mail: irene.barnes@fabi.up.ac.za
\end{abstract}

\author{
A. O. Al Adawi \\ Sultanate of Oman. \\ I. A. Khan \\ University of Agriculture, Faisalabad 38040, Pakistan
}

Ghadafan Agriculture Research Station, Ministry of Agricult and Fisheries, P. O. Box 204, Sohar 311,

M. L. Deadman

Department of Crop Sciences, P.O. Box 34, Sultan Qaboos University, Al Khod 123, Sultanate of Oman.

\begin{abstract}
Ceratocystis manginecans has recently been described from Oman and Pakistan where the fungus causes a serious wilt disease of mango. In both countries, the disease has moved rapidly throughout mango producing areas leading to the mortality of thousands of mango trees. The disease is associated with the infestation of the wood-boring beetle Hypocryphalus mangiferae that consistently carries $C$. manginecans. The aim of this study was to consider the population structure of $C$. manginecans isolated from Oman and Pakistan using microsatellite markers and amplified fragment length polymorphisms (AFLPs).
\end{abstract}


Population genetic analysis of $C$. manginecans isolates from diseased mango tissue and bark beetles associated with the disease in Oman and Pakistan, showed no genetic diversity. The apparently clonal nature of the population suggests strongly that $C$. manginecans was introduced into these countries as a single event or from another clonal source.

Keywords Ceratocystis acaciivora 'clonal populations ' insect transmission ' mango wilt

\section{Introduction}

Ceratocystis manginecans M. Van Wyk, A Al Adawi, and M.J. Wingf is a serious and relatively recently recognised pathogen causing wilt of mango trees (Mangifera indica L.) in Oman and Pakistan (Al Adawi et al. 2006; Al Adawi et al. 2013b; Van Wyk et al. 2007). Although mango has been planted in Oman and Pakistan for several centuries, the disease was first observed in 1998 in both countries. In Oman, mango wilt disease was first reported on a small number of trees in Barka, southern Al Batinah. The disease subsequently spread to all mango growing areas killing thousands of trees (Al Adawi et al. 2003; Al Adawi et al. 2006). Although the mango industry in Oman is relatively small (8600t per annum), it accounts for $30 \%$ of mango consumption in the country (Ministry of Agriculture and Fisheries [MAF] 2009b; Royal Oman Police [ROP] 2002; 2008). In contrast, Pakistan is a major mango producer and exporter, with production exceeding $1.7 \mathrm{mt}$ per annum and net profits from mango exports exceeding 20 million \$US (FAOSTAT 2007). The establishment and spread of mango wilt disease has resulted in substantial loss and threatens mango production in both countries (Kazmi et al. 2005; Al Adawi et al. 2006).

Disease symptoms in Oman and Pakistan include vascular discolouration, gummosis and wilt of part, or the whole of the infected trees. The disease is usually accompanied by 
visible infestation by the wood boring beetle Hypocryphalus mangiferae (Coleoptera: Scolytinae) (Al Adawi et al. 2006; Van Wyk et al. 2007). The first record of H. mangiferae attacking mango trees in Oman and Pakistan was concurrent with the first report of mango wilt disease. Furthermore, the pathogen responsible for the disease, $C$. manginecans (Al Adawi et al. 2006), was recovered from $H$. mangiferae isolated from diseased mango trees in both countries (Al Adawi et al. 2006; Van Wyk et al. 2007). In Oman, the high levels of recovery (13-83\%) of $C$. manginecans from $H$. mangiferae associated with the disease and the random distribution and rapid progress of mango wilt across northern Oman, has suggested the involvement of the bark beetle as vector for the pathogen (Al Adawi et al. 2006; Al Adawi et al. 2013a).

Ceratocystis manginecans was described as species in the C. fimbriata sensu lato complex (Van Wyk et al. 2007). This complex includes several newly described and numerous other unresolved species isolated from a wide range of hosts in many parts of the world (Webster and Butler 1967a; Webster and Butler 1967b; Kile 1993; Roux et al. 2000; Barnes et al. 2001; Baker et al. 2003; Van Wyk et al. 2013). Such species include $C$. albifundus M.J. Wingf., De Beer and Morris, the cause of a serious wilt disease of Acacia mearnsii (Wingfield et al. 1996); C. pirilliformis Barnes and M.J. Wingf. from Eucalyptus (Barnes et al. 2003); C. cacaofunsta Engelbrecht and Harrington from Theobroma cacao and C. platani Engelbrecht and Harrington from Platanus sp. (Engelbrecht and Harrington 2005). Mango wilt disease has been known in Brazil since the 1930s (Viegas 1960) and has similar symptoms to those observed in Oman and Pakistan. The causal agent of the disease in Brazil resides in the $C$. fimbriata complex that is believed to include a number of distinct taxa (Van Wyk et al. 2007; Harrington et al. 2011; Van Wyk et al. 2011; Van Wyk et al. 2013) but the relatedness of these to $C$. manginecans remains to be fully resolved. The purported vector of $C$. manginecans in Oman, H. mangiferae is also associated with mango wilt in Brazil 
(Castro 1960; Rossetto et al. 1980; Al Adawi et al. 2013a) where it is considered an invasive alien species.

In Sao Paulo State, Brazil, two strains of C. fimbriata s.l were found to be predominant. Mango varieties evaluated for resistance showed differential responses. The varieties Coração Boi, Espada, Ubá and Vitória were resistant to one strain but susceptible to the second (Ribeiro 1993; Ribeiro et al. 1995). Given the fact that the pathogen/s in Brazil may encompass a number of discrete taxa or is one having considerable genetic variability (Harrington et al. 2011; Van Wyk et al. 2011), information on population genetic structure will be important for the development of effective management strategies for mango wilt disease in Oman, Pakistan and elsewhere (McDonald 1997; McDonald and Linde 2002; Milgroom and Peever 2003).

The origin of $C$. manginecans in Pakistan and Oman is unknown but field evidence suggests that it is an introduced pathogen. It is known that there have been large consignments of mango fruit imported into Oman from Pakistan (ROP 2002; 2008) and the proximity of the two countries encourages regular unauthorised introductions of mango planting material into Oman from Pakistan (Al Adawi, personal observation). The health status of this material is difficult to determine but illicit trade represents a clear means by which pathogens could enter Oman.

The aim of this study was to gain an understanding of the population structure of $C$. manginecans isolates from both diseased mango trees and bark beetles associated with mango wilt in Oman and Pakistan by using two sets of microsatellite markers previously developed for C. fimbriata (Barnes et al. 2001; Steimel et al. 2004) and an AFLP (Vos et al. 1995) protocol. In this way, it was anticipated that it might be possible to better understand the origin of the pathogen in Oman and to inform programmes focussed on developing diseasetolerant planting stock. 


\section{Materials and methods}

Sampling and fungal isolations

Isolates of $C$. manginecans were collected from stems of diseased mango trees and $H$. mangiferae beetles in Oman and Pakistan. Samples from Oman were collected between November 2003 and June 2004 from five areas (Shinas, Liwa, Sohar, Rustaq and Quriayat) where disease incidence was high. Liwa and Shinas are within $50 \mathrm{~km}$ of Sohar while Rustaq and Quriayat are 110 and $250 \mathrm{~km}$ distant from each other respectively (Fig. 1). Between them, these areas represent $41.8 \%$ of the total mango production in Oman (Ministry of Agriculture and Fisheries [MAF] 2009a). Diseased mango samples from Pakistan were collected during May 2006 from Faisalabad and Multan (230 Km apart) in the province of Punjab (Fig. 2). In addition, thirty adult $H$. mangiferae were collected from mango trees from Faisalabad and Multan using an aspirator. Punjab represents $52 \%$ of the total area under mango cultivation in Pakistan with an annual production of over 700,000 tons (67\%) (Collins et al. 2006).

Samples were made by cutting pieces of woody tissue from the leading edges of lesions on the stems of trees. These samples were washed with tap water; surface disinfested in $1 \% \mathrm{NaOCl}$ for $1 \mathrm{~min}$, rinsed in sterile distilled water and blotted dry on sterile filter paper. To bait for, and induce sporulation of $C$. manginecans, infected wood pieces were incubated in moist chambers and/or placed between two slices of carrot pre-treated with streptomycin (100 mg/l) (Moller and DeVay 1968).

Single adult $H$. mangiferae beetles were crushed and placed in a cavity made on the inner surface of a pair of carrot discs pre-treated by soaking in a streptomycin solution. Carrot discs inoculated with either diseased wood pieces or beetles were incubated for 7-10 days at 


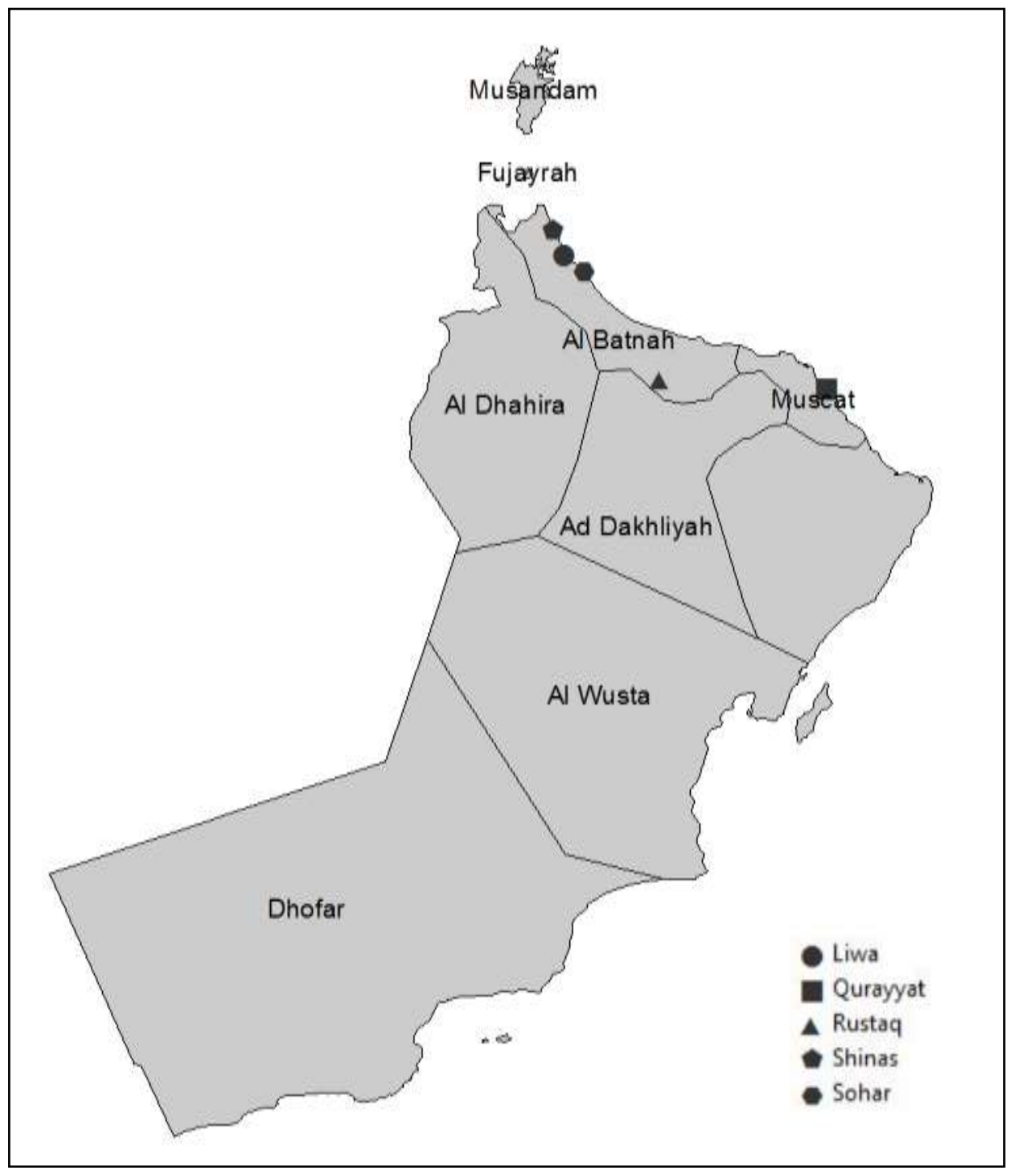

Fig. 1 Map of Oman showing the collection sites for C. manginecans 


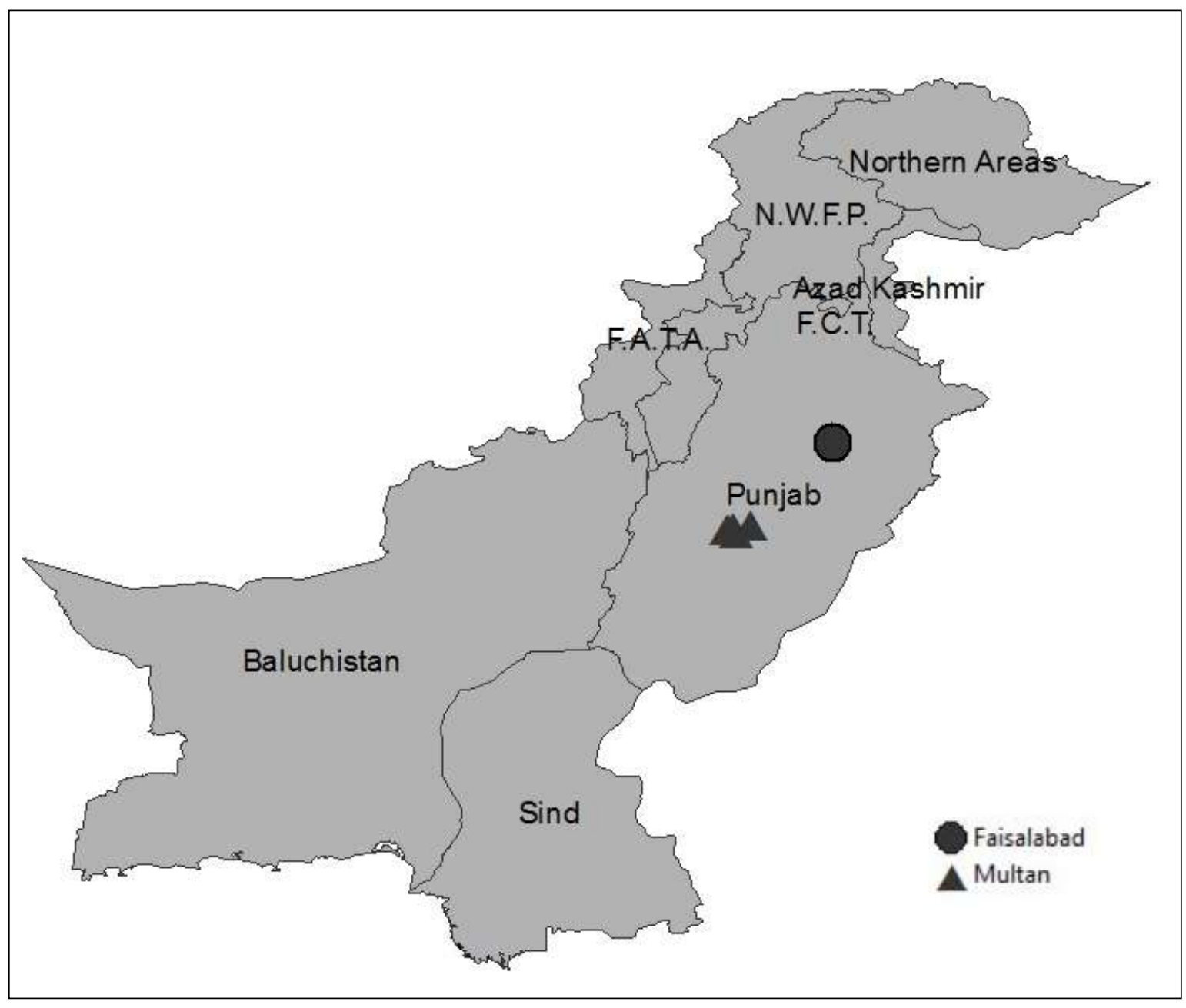

Fig. 2 Map of Pakistan showing the locations where $C$. manginecans was collected

room temperature $\left(22-25{ }^{\circ} \mathrm{C}\right)$ under conditions of high humidity. Once ascomata had developed on the carrot discs, single ascospore masses were transferred onto $2 \%$ malt extract agar (MEA) (Biolab, Midrand, South Africa) supplemented with streptomycin (100 mg/l).

To confirm pathogen identity, fungal structures from randomly selected ten-day-old cultures of isolates were transferred to glass slides, mounted in lactic acid and examined under a compound microscope. C. manginecans isolates were identified based on morphological characteristics such as colour of colonies, ascomatal shape, presence of hat shaped ascospores and production of cylindrical conidia (Van Wyk et al. 2007). All isolates used were preserved in the culture collection (CMW) at the Forestry and Agricultural Biotechnology Institute (FABI), University of Pretoria, South Africa (Table 1). 
Table 1 Isolates of Ceratocystis manginecans used in this study. Isolates of C. fimbriata s.l, C. mangicola, $C$. mangivora and C. platani were used as controls.

\begin{tabular}{|c|c|c|c|c|c|}
\hline Ceratocystis spp. & CMW isolates ${ }^{1}$ & Source & Area & Country & $\begin{array}{c}\text { Sample } \\
\text { size }\end{array}$ \\
\hline \multirow[t]{5}{*}{ C. manginecans } & $\mathbf{1 5 3 3 7}^{\mathbf{2}}-15353$ & $\begin{array}{c}\text { Mangifera } \\
\text { indica }\end{array}$ & Shinas & Oman & $16(2)^{3}$ \\
\hline & $\begin{array}{l}15366,15369,15370 \\
15385-15389,15391\end{array}$ & M. indica & Liwa & $"$ & $9(3)$ \\
\hline & $\begin{array}{c}\text { 15313, 15314, } 15315 \text { - } \\
\text { 15316, } 15367,15390\end{array}$ & M. indica & Sohar & $"$ & $6(3)$ \\
\hline & $15371-15377$ & M. indica & Quariyat & ” & $7(1)$ \\
\hline & & & & Total & $38(9)$ \\
\hline \multirow[t]{5}{*}{ C. manginecans } & $\mathbf{1 5 3 1 7}-15336$ & $\begin{array}{c}\text { Hypocryphalus } \\
\text { mangiferae }\end{array}$ & Sohar & Oman & $20(1)$ \\
\hline & $15354-15365,15384$ & H. mangiferae & Liwa & $"$ & $13(3)$ \\
\hline & 15368 & H. mangiferae & Rustaq & $"$ & $1(1)$ \\
\hline & $\begin{array}{c}15378-\mathbf{1 5 3 8 1}, \mathbf{1 5 3 8 2}, \\
\mathbf{1 5 3 8 3}, 15392\end{array}$ & H. mangiferae & Quariyat & ” & $7(1)$ \\
\hline & & & & Total & $41(6)$ \\
\hline \multirow[t]{4}{*}{ C. manginecans } & 17567 & M. indica & Faisalabad & Pakistan & $1(1)$ \\
\hline & 23637- 23642, 23643 & M. indica & Multan & $"$ & $7(3)$ \\
\hline & & & & Total & $8(4)$ \\
\hline & $\begin{array}{c}\mathbf{2 3 6 2 8}, 23629, \mathbf{2 3 6 3 0}- \\
\mathbf{2 3 6 3 4}, 23635,23636\end{array}$ & H. mangiferae & Faisalabad & Pakistan & $9(1)$ \\
\hline C. mangicola & 14797 & M. indica & - & Brazil & 1 \\
\hline C. mangivora & 15052 & M. indica & - & Brazil & 1 \\
\hline C. fimbriata s.l & 14806 & Ficus sp. & - & Brazil & 1 \\
\hline C. fimbriata s.l & 4903 & Eucalyptus sp. & - & Brazil & 1 \\
\hline \multirow[t]{3}{*}{ C. platani } & 1894 & Platanus sp. & - & Switzerland & 1 \\
\hline & 2219 & Platanus sp. & - & France & 1 \\
\hline & 2242 & Platanus sp. & - & Italy & 1 \\
\hline
\end{tabular}

\footnotetext{
${ }^{\mathrm{T}}$ All the C. manginecans isolates were collected by A. O. Al Adawi. All isolates are maintained in the culture collection (CMW) of the Forestry and Agriculture Biotechnology Institute (FABI), University of Pretoria, South Africa.

${ }^{2}$ Isolate number in bold were used in the AFLP analysis.

${ }^{3}$ Number in parenthesis indicates the number of sites where the samples were collected.
} 
DNA extraction

All isolates were grown on 2\% MEA and incubated for two weeks at $25{ }^{\circ} \mathrm{C}$. Mycelium, including ascomata and ascospores was scraped from the agar surface using a sterile spatula and transferred to $1.5 \mathrm{ml}$ Eppendorf tubes. These were freeze dried, the mycelium crushed to a fine powder using a glass rod and the DNA was extracted following the method described by Barnes et al. (2001). Extracted DNA was run on 1.5\% agarose gels stained with ethidium bromide. The presence and intensity of the extracted DNA for each isolate was examined under ultraviolet (UV) illumination. DNA concentrations were determined using a Nanodrop ND-1000 Spectrophotometer (Nanodrop Technologies, Rockland, Delaware) and DNA dilutions $(30-60 \mathrm{ng} / \mu \mathrm{l})$ made with sterile distilled water.

SSR-PCR and genescan analysis

Cross-species amplification of the available 27 microsatellite markers developed for $C$. fimbriata (Barnes et al. 2001; Steimel et al. 2004) were tested on three isolates of $C$. manginecans. PCRs were performed using $25 \mu \mathrm{l}$ reaction mixtures consisting of $2 \mathrm{ng}$ DNA, $2.5 \mu \mathrm{l}$ of Expand HF buffer containing $1.5 \mathrm{mM} \mathrm{MgCl} 2,300 \mathrm{nM}$ of the forward and reverse microsatellite primers, $200 \mu \mathrm{M}$ of $\mathrm{dNTP}$ and $0.35 \mathrm{U}$ of Taq polymerase. Amplification of microsatellite primers was carried out using an Eppendorf thermocycler programmed as described previously (Barnes et al. 2001; Steimel et al. 2004). PCR products were separated by electrophoresis on a $1.5 \%$ agarose gel stained with ethidium bromide and visualized under UV light.

Primers that successfully amplified $C$. manginecans were used on the isolates obtained from Oman and Pakistan following the same methods described above. Primers were 
fluorescently labelled with PET, VIC, FAM or NED dyes using the G5 labelling kit (Applied Biosystems, Warrington, UK).

Microsatellite products were multiplexed according to the fluorescent dye and the amplicon size. This was to enable the simultaneous analysis of the maximum possible loci in a single gel run. The fluorescently labelled SSR-PCR amplicons $(0.5 \mu 1$ containing approx. $1.5 \mathrm{ng}$ DNA) were mixed with $0.4 \mu \mathrm{l}$ GeneScan-500 Liz internal size standard (Applied Biosystems Inc., Foster City, California) and $10 \mu \mathrm{l}$ formamide. The majority of samples were run on an ABI Prism 377 DNA sequencer (Applied Biosystems Inc., Foster City, California) and the remaining samples were separated using an ABI Prism 3100 DNA sequencer. Due to allele shifts between instruments, three reference samples were analyzed on both instruments. GENOMAPPER version 3.0 (Applied Biosystems Inc., Foster City, California)was used to analyze gels and determine allele sizes. All gel runs contained the same reference samples to ensure reproducibility.

All alleles that were only one base pair different from each other at a locus were sequenced to confirm the allele scoring. The PCR reactions for three isolates (CMW15337, $23629,23637)$ of $C$. manginecans were repeated using same conditions described above but with non-fluorescent primers. The PCR products were purified using 6\% Sephadex G-50 columns (1 g sephadex in $15 \mathrm{ml}$ sterile water, Sigma-Aldrich, Steinheim, Germany). Sequencing reactions were prepared using 5-10 ng of cleaned PCR product, $1 \mu \mathrm{l}$ primer, $2 \mu \mathrm{l}$ $5 \mathrm{x}$ sequencing buffer, $2 \mu \mathrm{l}$ of ABI Prism Big Dye Terminator mix, v. 3. 1 (Applied Biosystems Inc., Foster City, California) in a total volume of $10 \mu 1$. Sequencing PCR consisted of 25 cycles at $96^{\circ} \mathrm{C}$ for $10 \mathrm{~s} ; 50^{\circ} \mathrm{C}$ for $4 \mathrm{~s} ; 60^{\circ} \mathrm{C}$ for $4 \mathrm{~min}$. Sequencing reactions were cleaned using Sephadex G-50. Sequences were determined using an ABI PRISM 3100 Autosequencer (Applied Biosystems Inc., Foster City, California) and aligned using MEGA 4.0 (Tamura et al. 2011). 
Selected isolates from the $C$. fimbriata s.l complex from Brazil (including $C$. mangicola and $C$. mangivora) and $C$. platani were included in this study (Table 1 ) to test the robustness of the microsatellite locus amplification and for comparison with $C$. manginecans isolates.

AFLP analyses

Twenty two isolates of $C$. manginecans (ten from Oman and 12 from Pakistan) and three isolates of $C$. platani were screened using the AFLP protocol (Vos et al. 1995) modified by (Myburg et al. 2001) (Table 1). DNA was digested using restriction endonucleases EcoRI and MseI and the restricted fragments were ligated to the corresponding adapters. The preamplification reaction was performed with two pre-selective primers (M E00 and M M00) using the following PCR mixture: $5 \mu$ Restriction/ Ligation (R/L) mixtures; 1x PCR buffer; $0.2 \mathrm{mM}$ dNTPs and 1.5 units Taq polymerase. The PCR conditions for pre-amplification of the R/L DNA fragments involved: $30 \mathrm{~s}$ at $72{ }^{\circ} \mathrm{C}, 25$ cycles of $30 \mathrm{~s}$ at $94{ }^{\circ} \mathrm{C}, 30 \mathrm{~s}$ at $56^{\circ} \mathrm{C}$, and 1 min at $72{ }^{\circ} \mathrm{C}$ with an increment of $1 \mathrm{~s}$ per cycle, followed by 2 min at $72{ }^{\circ} \mathrm{C}$. The PCR mixture for selective amplification was carried out as above using one primer combinations $(\mathrm{Mo} 4+\mathrm{E}-\mathrm{AC})$ and the EcoRI primer was labelled with the infrared dye, IRDye 700 (LICOR, Lincoln, NE). The final PCR amplification consisted of 13 cycles of $10 \mathrm{~s}$ at $94{ }^{\circ} \mathrm{C}, 30 \mathrm{~s}$ at $65^{\circ} \mathrm{C}$ with a decrement of $0.7^{\circ} \mathrm{C}$ per cycle, $1 \mathrm{~min}$ at $72{ }^{\circ} \mathrm{C}$; followed by 23 cycles of $10 \mathrm{~s}$ at $94{ }^{\circ} \mathrm{C}, 30 \mathrm{~s}$ at $56^{\circ} \mathrm{C}, 1 \mathrm{~min}$ at $72{ }^{\circ} \mathrm{C}$ with an increment of $1 \mathrm{~s}$ per cycle; and a final extension step at $72{ }^{\circ} \mathrm{C}$ for $1 \mathrm{~min}$. Formamide loading buffer was added to the products resulting from the final amplification and these were run on a polyacrylamide gel using automated DNA sequencer 4200 LI-COR (Myburg et al. 2001). AFLP gel images generated from LI-COR automated sequences were visually evaluated and banding patterns of $C$. manginecans 
isolated from mango and $H$. mangiferae from Oman and Pakistan were compared to the $C$. platani isolates.

\section{Results}

Sampling and isolations

Seventy nine isolates of $C$. manginecans were collected from diseased mango trees and from bark beetles (H. mangiferae) from five areas of Oman (Table 1; Fig. 1). Isolations from Faisalabad, Pakistan, yielded 17 C. manginecans isolates, nine of which were from bark beetles (Table 1; Fig. 2). In total, 96 isolates of $C$. manginecans, three isolates of $C$. platani, one isolate each of $C$. mangicola and $C$. mangivora from mango in Brazil and two isolates from the $C$. fimbriata s.l clade representing those from different hosts were used for the SSR studies (Table 1).

SSR-PCR and genescan analysis

From the 27 loci amplified with the microsatellite markers, five loci (AG15/16, AG17/18, CF21/22, CAG900 and GACA60) were excluded from the analysis as they produced monomorphic alleles in all isolates, including those from the $C$. fimbriata s.l group. Loci AG1/2, AG7/8, CF11/12, CF15/16, CF17/18, CF23/24 and CAT1200 amplified alleles with a one base pair polymorphism. After sequencing, $100 \%$ sequence similarity was found between the alleles that had one base pair difference between them. They were thus scored as a single allele with the following sizes; 264, 283, 219, 474, 270, 158 and 373. 
Sizes of the SSR-PCR products in the remaining 22 loci ranged from 123 to $480 \mathrm{bp}$. In the $C$. manginecans populations from Oman and Pakistan, 79 alleles were obtained from the amplification of twenty two polymorphic SSR loci (Table 2). Two alleles amplified in loci CF11/12 and AAG9 but in both cases, one of the alleles had a low allele frequency value of 0.03 and 0.01 respectively (Table 3 ). The remaining loci yielded monomorphic alleles in all isolates of C. manginecans from Oman and Pakistan. Therefore, in almost all loci examined, the allelic frequency values were one and gene diversity values were zero for the $C$. manginecans isolates from Oman and Pakistan (Table 3). All isolates of $C$. manginecans from either diseased mango or bark beetles represented a single multilocus genotype for the above mentioned loci. Furthermore, all the $C$. manginecans isolates had the same alleles as $C$. mangicola and $C$. mangivora from mango in Brazil at nine of the loci (40.1\%) and they shared the same allele with the Brazilian fig and Eucalyptus isolates at six loci $(27.3 \%)$. The C. mangicola and C. mangivora isolates varied from each other at 6 loci. C. platani isolates shared the same alleles with the $C$. manginecans populations in two microsatellite loci (9\%) (Table 2).

Three loci (AAG9, CAT3K and CAT9X) amplified more than one allele per locus within the Oman and Pakistan C. manginecans population. Locus AAG9, amplified multiple alleles in one isolate of $C$. manginecans from Oman. One of these alleles was the same as that in the Brazilian mango (C. mangicola and C. mangivora) and Eucalyptus isolates of $C$. fimbriata s.l. In addition, locus CAT3K amplified double alleles (309/321) for $C$. manginecans isolated from Oman and Pakistan and shared one of the alleles (309) with all the Brazilian isolates, irrespective of their host origin (Table 2). 
Table 2. Alleles sizes for $C$. manginecans populations collected from Oman and Pakistan revealed through the amplification of 22 microsatellite loci. Allele sizes for $C$. mangicola, C. mangivora, C. fimbriata s.l and C. platani are also included for comparison purposes.

\begin{tabular}{|c|c|c|c|c|c|c|c|c|c|c|c|}
\hline \multirow{4}{*}{$\begin{array}{c}\text { Species } \\
\text { Locus/ } \\
\text { Host }\end{array}$} & \multirow{2}{*}{\multicolumn{2}{|c|}{$\begin{array}{c}\text { Oman } \\
\text { C. manginecans }\end{array}$}} & \multirow{2}{*}{\multicolumn{2}{|c|}{$\begin{array}{c}\text { Pakistan } \\
\text { C. manginecans }\end{array}$}} & \multicolumn{3}{|c|}{ Brazil } & \multirow{3}{*}{$\begin{array}{c}\text { France } \\
\text { C. platani } \\
\begin{array}{c}\text { Platanus } \\
\text { sp. }\end{array}\end{array}$} & \multirow{3}{*}{$\begin{array}{c}\text { Italy } \\
\text { C. platani } \\
\begin{array}{c}\text { Platanus } \\
\text { sp. }\end{array}\end{array}$} & \multirow{3}{*}{$\begin{array}{l}\text { Switzerland } \\
\text { C. platani } \\
\text { Platanus sp. }\end{array}$} & \multirow{4}{*}{$\begin{array}{l}\text { No of } \\
\text { alleles }\end{array}$} \\
\hline & & & & & \multirow{2}{*}{$\begin{array}{c}\text { C. mangicolal } \\
\text { C. mangivora } \\
\text { M. indica }\end{array}$} & \multicolumn{2}{|c|}{ C. fimbriata s.l } & & & & \\
\hline & M. indica & H. mangiferae & M. indica & $\begin{array}{c}H . \\
\text { mangiferae }\end{array}$ & & $\begin{array}{l}\text { Ficus } \\
\text { sp. }\end{array}$ & $\begin{array}{l}\text { Eucalyptus } \\
\text { sp. }\end{array}$ & & & & \\
\hline & $(38)^{\mathrm{A}}$ & (41) & (8) & (9) & (2) & (1) & (1) & (1) & (1) & (1) & \\
\hline AG1/2 & 264 & 264 & 264 & 264 & $264^{\mathrm{D}}$ & 264 & 262 & 266 & 266 & 266 & 3 \\
\hline AG7/8 & 283 & 283 & 283 & 283 & 283 & 286 & 289 & 286 & 286 & 286 & 3 \\
\hline CF5/6 & 365 & 365 & 365 & 365 & 365 & 365 & 365 & 376 & 376 & 376 & 2 \\
\hline CF11/12 & $\begin{array}{l}217(2)^{\mathrm{B}}, \\
219(36)\end{array}$ & 219 & 219 & 219 & 219 & 214 & 219 & 230 & 230 & 230 & 4 \\
\hline CF13/14 & 406 & 406 & 406 & 406 & 406 & 417 & 406 & 415 & 415 & 415 & 3 \\
\hline CF15/16 & 474 & 474 & 474 & 474 & 472 & 477 & 477 & 480 & 480 & 480 & 4 \\
\hline CF17/18 & 270 & 270 & 270 & 270 & $\mathbf{2 7 0}, 278$ & 270 & 268 & 270 & 270 & 270 & 3 \\
\hline CF23/24 & 158 & 158 & 158 & 158 & 152,160 & 158 & 155 & 160 & 160 & 160 & 4 \\
\hline AAG8 & 176 & 176 & 176 & 176 & 174 & 179 & 179 & 174 & 174 & 174 & 3 \\
\hline AAG9 & 404 & $\begin{array}{c}404(40), \\
404 / 399(1)^{\mathrm{C}}\end{array}$ & 404 & 404 & 399 & 402 & 399 & 407 & 407 & 407 & 5 \\
\hline CAA9 & 224 & 224 & 224 & 224 & 174,204 & 200 & 174 & - & 204 & - & 4 \\
\hline CAA10 & 123 & 123 & 123 & 123 & 129,132 & 132 & 132 & 126 & 126 & 126 & 4 \\
\hline CAA15 & 324 & 324 & 324 & 324 & 324 & 330 & 321 & 315 & 315 & 315 & 4 \\
\hline CAA38 & 338 & 338 & 338 & 338 & - & 330 & 338 & 338 & - & - & 2 \\
\hline CAA80 & 304 & 304 & 304 & 304 & 323,328 & 323 & 311 & - & 308 & - & 5 \\
\hline CAT1 & 252 & 252 & 252 & 252 & 255 & 252 & 262 & 255 & 255 & 255 & 3 \\
\hline CAT3K & $309 / 321$ & $309 / 321$ & $309 / 321$ & $309 / 321$ & 309 & 309 & 309 & - & 309 & 309 & 3 \\
\hline САТ9X & $274 / 280$ & $274 / 280$ & $274 / 280$ & $274 / 280$ & 268 & 271 & $280 / 286$ & $279 / 282$ & $279 / 282$ & $279 / 282$ & 5 \\
\hline CAT1200 & 373 & 373 & 373 & 373 & 373 & 382 & 377 & 390 & - & - & 4 \\
\hline CAG5 & 319 & 319 & 319 & 319 & 319 & 337 & 319 & 328 & - & - & 3 \\
\hline CAG15 & 270 & 270 & 270 & 270 & 260,283 & 274 & 255 & - & - & - & 5 \\
\hline GACA650 & 214 & 214 & 214 & 214 & 220 & 208 & 214 & - & - & - & 3 \\
\hline
\end{tabular}

${ }^{A}$ Number of isolates used in the study.

${ }^{\text {B }}$ Number of isolates in population with specific allele.

${ }^{\mathrm{C}}$ Two alleles were produced during amplification in a single individual.

${ }^{D}$ Alleles that are shared with those found in Oman/Pakistan are indicated in bold. 
Table 3 Summary statistics for Ceratocystis manginecans isolates from Pakistan and Oman using 22 microsatellite markers.

\begin{tabular}{|c|c|c|c|c|c|c|c|c|c|c|}
\hline \multirow{3}{*}{ Loci } & \multicolumn{2}{|c|}{ No. of isolates } & \multicolumn{2}{|c|}{ No. of alleles } & \multicolumn{4}{|c|}{ Allele frequency } & \multicolumn{2}{|c|}{$\mathrm{H}^{1}$} \\
\hline & \multirow[t]{2}{*}{ Oman } & \multirow[t]{2}{*}{ Pakistan } & \multirow[t]{2}{*}{ Oman } & \multirow[t]{2}{*}{ Pakistan } & \multicolumn{2}{|c|}{ Oman } & \multicolumn{2}{|c|}{ Pakistan } & \multirow[t]{2}{*}{ Oman } & \multirow[t]{2}{*}{ Pakistan } \\
\hline & & & & & $\mathrm{A}$ & $\mathrm{B}$ & $\mathrm{A}$ & $\mathrm{B}$ & & \\
\hline $\mathrm{AG} 1 / 2$ & 79 & 7 & 1 & 1 & 1.00 & & 1.00 & & 0.00 & 0.00 \\
\hline $\mathrm{AG} 7 / 8$ & 79 & 17 & 1 & 1 & 1.00 & & 1.00 & & 0.00 & 0.00 \\
\hline CF5/6 & 79 & 17 & 1 & 1 & 1.00 & & 1.00 & & 0.00 & 0.00 \\
\hline CF11/12 & 79 & 17 & 2 & 1 & 0.97 & 0.03 & 1.00 & & 0.05 & 0.00 \\
\hline CF13/14 & 79 & 17 & 1 & 1 & 1.00 & & 1.00 & & 0.00 & 0.00 \\
\hline CF15/16 & 79 & 16 & 1 & 1 & 1.00 & & 1.00 & & 0.00 & 0.00 \\
\hline CF17/18 & 79 & 17 & 1 & 1 & 1.00 & & 1.00 & & 0.00 & 0.00 \\
\hline $\mathrm{CF} 23 / 24$ & 79 & 17 & 1 & 1 & 1.00 & & 1.00 & & 0.00 & 0.00 \\
\hline AAG8 & 79 & 13 & 1 & 1 & 1.00 & & 1.00 & & 0.00 & 0.00 \\
\hline AAG9 & 79 & 17 & 2 & 1 & 0.99 & 0.01 & 1.00 & & 0.03 & 0.00 \\
\hline CAA9 & 78 & 17 & 1 & 1 & 1.00 & & 1.00 & & 0.00 & 0.00 \\
\hline CAA 10 & 77 & 17 & 1 & 1 & 1.00 & & 1.00 & & 0.00 & 0.00 \\
\hline CAA15 & 78 & 17 & 1 & 1 & 1.00 & & 1.00 & & 0.00 & 0.00 \\
\hline CAA38 & 73 & 16 & 1 & 1 & 1.00 & & 1.00 & & 0.00 & 0.00 \\
\hline CAA80 & 78 & 17 & 1 & 1 & 1.00 & & 1.00 & & 0.00 & 0.00 \\
\hline CAT1 & 76 & 17 & 1 & 1 & 1.00 & & 1.00 & & 0.00 & 0.00 \\
\hline CAT3K & 79 & 17 & 1 & 1 & 1.00 & & 1.00 & & 0.00 & 0.00 \\
\hline CAT9X & 79 & 17 & 1 & 1 & 1.00 & & 1.00 & & 0.00 & 0.00 \\
\hline CAT1200 & 79 & 17 & 1 & 1 & 1.00 & & 1.00 & & 0.00 & 0.00 \\
\hline CAG5 & 77 & 17 & 1 & 1 & 1.00 & & 1.00 & & 0.00 & 0.00 \\
\hline CAG15 & 79 & 16 & 1 & 1 & 1.00 & & 1.00 & & 0.00 & 0.00 \\
\hline GACA650 & 79 & 17 & 1 & 1 & 1.00 & & 1.00 & & 0.00 & 0.00 \\
\hline
\end{tabular}

${ }^{1} \mathrm{H}=$ Nei's (1973) gene diversity 
AFLP profiles

The AFLP profiles of 18 loci for all isolates of $C$. manginecans isolated from diseased mango trees and bark beetles associated with mango wilt disease in Oman and Pakistan were identical. The three isolates of $C$. platani from Platanus, that were used as controls, shared 14/18 (78\%) bands with the C. manginecans isolates in Mo4 + E-AC primer combination. In addition, 10 unique AFLP bands were present in the profiles of the $C$. platani isolates and these bands were not present in the $C$. manginecans profiles.

\section{Discussion}

Microsatellite and AFLP analyses in this study showed a lack of variation amongst isolates of C. manginecans. Furthermore, there were no intra or inter geographical differences between C. manginecans isolates from Oman and Pakistan or between isolates from mango trees or bark beetles. The results, therefore, suggest a recent founder event with $C$. manginecans having been recently introduced and established in the region.

Results of this study affirm the efficacy of the microsatellite markers developed previously for $C$. fimbriata s.l. for studying populations of isolates of $C$. manginecans, $C$. mangivora, C. mangicola as well as $C$. albifundus, $C$. platani, $C$. cacaofunesta and $C$. pirilliformis (Engelbrecht et al. 2004; Barnes et al. 2005; Engelbrecht et al. 2007; Kamgan et al. 2009). This might indicate that flanking regions surrounding these markers are highly conserved across taxa, allowing cross species amplification of those markers (Selkoe and Toonen 2006).

The overall genetic analysis of $C$. manginecans isolates from Oman and Pakistan has shown that they represent a single clone of the pathogen. This supports the view that mango 
wilt disease in Oman and Pakistan emerged from single introduction of a single haplotype and the population has expanded clonally to infect mango trees in many parts of both countries. However, the source of $C$. manginecans in Oman and Pakistan is unknown. Tracking records of customs and plant quarantine offices in Oman has revealed that there have been regular importations of mango fruit and germplasm from India and Pakistan (Royal Oman Police [ROP] 2002; 2008). In addition, there is evidence of illegal introductions of mango seedlings into Oman from Pakistan that is facilitated by the proximity of the two countries (Al Adawi, personal observation). It is, therefore, possible that Pakistan represents the source of infection in Oman.

There are possible origins of $C$. manginecans in Oman other than Pakistan. For example, there are recent but inconclusive observations that mango wilt disease is in India and Bangladesh (Ploetz and Freeman 2009; Mosharraf Hossain, personal communication) and this might be the source of the infections in both Pakistan and Oman. Results of this study, however, provide no clues as to the origin of the pathogen. The fungus has been found on Acacia mangium in Indonesia (Tarigan et al. 2011), a country where mango is also widely planted. Alternatively $C$. manginecans could originate from South America, which appears to be an area of substantial genetic variation for $C$. fimbriata s.l., including the many cryptic species encompassed by this group (Barnes et al. 2001; Baker et al. 2003; Engelbrecht and Harrington 2005; Rodas et al. 2008; Van Wyk et al. 2009; Van Wyk et al. 2010; Van Wyk et al. 2011).

Prevention of further introductions of $C$. manginecans into Oman and Pakistan will be important as this will preclude an expansion of the genetic diversity of the pathogen in these countries. C. manginecans reproduces asexually via conidia and by ascospores arising from unidirectional mating type switching (Webster and Butler 1967a; Webster and Butler 1967b; Harrington and McNew 1997; Witthuhn et al. 2000). The fungus is able to outcross and there 
is emerging evidence of hybrids between species in the C. fimbriata s.l. complex (Naidoo et al. 2013; Fourie et al. unpublished). A greater genetic diversity in $C$. manginecans, emerging from sexual outcrossing or hybridisation will complicate efforts to manage mango wilt disease in Oman and neighbouring countries. Clearly, every effort should be made to prevent the introduction of strains of $C$. manginecans or other species in the $C$. fimbriata s.l. complex.

The lack of genetic variation between isolates of $C$. manginecans from $H$. mangiferae and mango in Oman and Pakistan suggests the direct involvement of $H$. mangiferae as a vector for the spread of the fungus in these countries (Rossetto et al. 1980; Al Adawi et al. 2006; Van Wyk et al. 2007; Masood et al. 2008; Al Adawi et al. 2013a). H. mangiferae is host specific on mango and is indigenous to southern Asia where mango originated. Other than in Brazil, Oman and Pakistan where the insect is found in association with $C$. manginecans, $H$. mangiferae also occurs in many parts of the world including India, Malaysia, Indonesia and southern Florida where mango wilt disease is not known (Wood 1982; Butani 1993; Atkinson and Peck 1994). However, C. manginecans was recently reported in Indonesia associated with wilt and die-back disease on Acacia spp (Tarigan et al. 2011) and C. fimbriata s.l has been reported to cause disease on various crops including coffee (Coffea arabica L.), taro (Colocasia esculenta), pomegranate (Punica granatum) and rubber (Hevea brasiliensis) in the same area (Ploetz and Prakash 1997; Somasekhara 1999). Yet there has been no connection between these diseases and H. mangiferae, suggesting that the $C$. manginecans has not co-evolved with the insect (Ploetz and Freeman 2009).

The management of mango wilt disease involves using systematic fungicides and resistance mango cultivars (Rossetto et al. 1996; Ploetz and Freeman 2009; Al Adawi et al. 2013c). The development of genetic material resistant to the mango wilt pathogen, $C$. manginecans, is considered an important element in disease management. The Ministry of Agriculture in Oman, in collaboration with FAO, has begun a programme to introduce new 
mango germplasm from Brazil and Australia and to evaluate this for to infection by $C$. manginecans under local conditions. The results of the present study showing clonality of the pathogen in Oman suggests that selection and breeding for resistance will be simpler than it would have been if $C$. manginecans were represented a diverse population of isolates.

Acknowledgment We thank the members of the Tree Protection Co-operative Programme (TPCP), National Research Foundation (NRF), South Africa and the Ministry of Agriculture and Fisheries in Sultanate of Oman for funding this research. The Nuclear Institute for Agriculture and Biology (NIAB), Pakistan, is acknowledged for facilitating the collection of isolates. We also thank Lieschen de Vos for assistance with the AFLP experiments and William M. Deadman for assistance with map design. 


\section{References}

Al Adawi AO, Deadman ML, Al Rawahi AK, Khan AJ, Al Maqbali YM (2003) Diplodia theobromae associated with sudden decline of mango in the Sultanate of Oman. Plant Pathol 52:419-419

Al Adawi AO, Deadman ML, Al Rawahi AK, Al Maqbali YM, Al Jahwari AA, Al Saadi BA, Al Amri IS, Wingfield MJ (2006) Aetiology and causal agents of mango sudden decline disease in the Sultanate of Oman. Eur J Plant Pathol 116:247-254

Al Adawi AO, Al Jabri RM, Deadman ML, Barnes I, Wingfield B, Wingfield MJ (2013a) The mango sudden decline pathogen, Ceratocystis manginecans, is vectored by Hypocryphalus mangiferae (Coleoptera: Scolytinae) in Oman. Eur J Plant Pathol $135: 243-251$

Al Adawi AO, Barnes I, Khan IA, Al Subhi AM, Deadman ML, Al Jahwari AA, Wingfield BD, Wingfield MJ (2013b) Ceratocystis manginecans associated with a serious wilt disease of two native legume trees in Oman and Pakistan. Australas Plant Pathol 42:179-193

Al Adawi AO, Al Sadi BA, Deadman ML, Barnes I, Al Jabri MH, Wingfield BD, Wingfield MJ (2013c) Evaluation of mango cultivars for resistance to infection by Ceratocystis manginecans. Acta Horticulturae 992:393-406

Atkinson TH, Peck SB (1994) Annotated checklist of the bark and ambrosia beetles (Coleoptera: Platypodidae and Scolytidae) of tropical Southern Florida. Fla Entomol Online 77:313-329

Baker CJ, Harrington TC, Krauss U, Alfenas AC (2003) Genetic Variability and Host Specialization in the Latin American Clade of Ceratocystis fimbriata. Phytopathology 93: $1274-1284$ 
Barnes I, Guar A, Burgess T, Roux J, Wingfield BD, Wingfield MJ (2001) Microsatellite markers reflect intra-specific relationships between isolates of the vascular wilt pathogen Ceratocystis fimbriata. Molecular Plant Pathol 2:319-325

Barnes I, Roux J, Wingfield BD, Dudzinski MJ, Old KM, Wingfield MJ (2003) Ceratocystis pirilliformis, a new species from Eucalyptus nitens in Australia. Mycologia 95:865871

Barnes I, Nakabonge G, Roux J, Wingfield BD, Wingfield MJ (2005) Comparison of populations of the wilt pathogen Ceratocystis albifundus in South Africa and Uganda. Plant Pathol 54:189-195

Butani DK (1993) Mango: Pest Problems. In: Periodical Expert Book. Agency D-42, Vivek Vihar: Delhi, India pp 290

Castro RdaS (1960) Contribuicao ao estudo de Hypocryphalus mangiferae (Stebbing, 1914) (Coleoptera, Scolytidae). [Contribution to the study of the "Hypocryphalus mangiferae (Stebbing, 1914) (Coleopter - Scolytidae)] biological cycle and etiology] In: Ciclo biologico e etiologia. Recife. Tese para concurso de professor livre-docente da 9.a cadeira-entomologia e parasitologia agricolas- da Escola Superior de Agricultura da Universidade Rural de Pernambuco, 54p.

Collins R, Dunne T, Campbell J, Johnson P, Malik A (2006) A constraints analysis of Pakistan mango supply chains. Study carried out under the auspices of the AustraliaPakistan Agriculture Sector Linkages Program, 35p.

Engelbrecht CJB, Harrington TC, Steimel J, Capretti P (2004) Genetic variation in the eastern American and putatively introduced population of Ceratocystis fimbriata f. platani. Mol Ecol 13:2995-3005

Engelbrecht CJB, Harrington TC (2005) Intersterility, morphology and taxonomy of Ceratocystis fimbriata on sweet potato, cacao and sycamore. Mycologia 97:57-69 
Engelbrecht CJB, Harrington TC, Alfenas AC, Suarez C (2007) Genetic variation in populations of the cacao wilt pathogen, Ceratocystis cacaofunesta. Plant Pathol $56: 923-933$

FAOSTAT (2007). In: FAOSTAT. Rome. United Nations Food and Agriculture Organization. On-line.

Harrington TC, McNew DL (1997) Self fertility and uni-directional mating-type switching in Ceratocystis coerulescens, a filamentous ascomycete. Curr Genet 32:52-59

Harrington TC, Thorpe DJ, Alfenas AC (2011) Genetic variation and variation in aggressiveness to native and exotic hosts among Brazilian populations of Ceratocystis fimbriata. Phytopathology 101:555-566.

Kamgan NG, Barnes I, Wingfield MJ, Roux J (2009) Distribution and population diversity of Ceratocystis pirilliformis in South Africa. Mycologia 101:17-25

Kazmi MR, Fateh FS, Majeed K, Kashkhely AM, Hussain I, Ahmad I, Jabeen A (2005) Incidence and etiology of mango sudden death phenomenon in Pakistan. Pak J Phytopathol 17:154-158

Kile GA (1993) Plant diseases caused by species of Ceratocystis sensu stricto and Chalara. In: Wingfield MJ, Seifert KA, Webber JF (eds) Ceratocystis and Ophiostoma: Taxonomy, Ecology and Pathogenicity. APS Press, St Paul, pp 173-183

Masood A, Saeed S, Sajjad A (2008) Characterization and damage patterns of different bark beetle species associated with mango sudden death syndrome in Punjab, Pakistan. Pak Entomol 30:163-168

McDonald BA (1997) The population genetics of fungi: Tools and techniques. Phytopathology 87:448-453

McDonald BA, Linde C (2002) Pathogen population genetics, evolutionary potential, and durable resistance. Annu Rev Phytopathol 40:349-379 
Milgroom MG, Peever TL (2003) Population biology of plant pathogens: the synthesis of plant disease epidemiology and population genetics. Plant Dis 87:608-617

Ministry of Agriculture and Fisheries (MAF). (2009a). Data base of agriculture sector: Agricultural census 2004/05. On-line.

Ministry of Agriculture and Fisheries (MAF). (2009b). Data base of agriculture sector: Agricultural production 2006-2008. On-line.

Moller W, DeVay J (1968) Insect transmission of Ceratocystis fimbriata in deciduous fruit orchards. Phytopathology 58:1499-1508

Myburg AA, Remington DL, O’Malley DM, Sederoff RR, Whetten RW (2001) Highthroughput AFLP analysis using infrared dye-labeled primers and an automated DNA sequencer. BioTechniques 30:348-357

Naidoo K, Steenkamp ET, Coetzee MP, Wingfield MJ, Wingfield BD (2013) Concerted evolution in the ribosomal RNA cistron. PloS one 8:e59355

Ploetz RC, Prakash O (1997) Foliar, floral and soil-borne diseases. In: Litz RE (ed) The Mango: Botany, Production and Uses. CAB International, Wallingford, pp 281-325

Ploetz RC, Freeman S (2009) Foliar, floral and soilborne diseases. Litz RE (ed) The Mango ( $2^{\text {nd }}$ ed). CAB International, Wallingford, pp 231-302

Ribeiro IJA (1993) Selecao de porta-enxertos de mangueira (Mangifera indica L.) resistentes ao fungo Ceratocystis fimbriata Ell. \& Halst. [Selection of mango varieties resistant to fungus Ceratocystis fimbriata Ell, \& Halst.] PhD thesis, Universidade Estadual Paulista, Campus de Jaboticabal, Sao Paulo, Brazil, 115p

Ribeiro IJA, Rosetto CJ, Donadio LC, Sabino JC, Martins ALM, Gallo PB (1995). Mango wilt. XIV Selection of mango (Mangifera indica L.) rootstocks resistant to the mango wilt fungus Ceratocystis fimbriata Ell \& Halst. Acta Hort 370: 159-161 
Rodas CA, Roux J, Van Wyk M, Wingfield BD, Wingfield MJ (2008) Ceratocystis neglecta sp. nov., infecting Eucalyptus trees in Colombia. Fungal Diver 28:73-84

Rossetto CJ, Ribeiro IJA, Igue T (1980) Seca da mangueira. III. Comportamento de variedades de mangueira, especies de coleobrocas e comportamento de Hypocryphalus mangiferae. [Mango wilt. III - Behavior of mango varieties, species of coleoptera and behavior of Hypocryphalus mangiferae]. Circular no. 106. Instituto Agronomico. Campinas, 44p

Rossetto CJ, Ribeiro IJA, Igue T, Gallo PB (1996) Seca-da-mangueira: XV. Resistência varietal a dois isolados de Ceratocystis fimbriata. Bragantia 55:117-121

Roux J, Wingfield MJ, Bouillet JP, Wingfield BD, Alfenas AC (2000) A serious new wilt disease of Eucalyptus caused by Ceratocystis fimbriata in Central Africa. Eur J Forest Pathol 30:175-184

Royal Oman Police (ROP) (2002) Foreign trade statistics: imports to Sultanate of Oman. $5454 p$

Royal Oman Police (ROP) (2008) Foreign trade statistics: imports to Sultanate of Oman. $5841 \mathrm{p}$

Selkoe KA, Toonen RJ (2006) Microsatellites for ecologists: a practical guide to using and evaluating microsatellite markers. Ecol Lett 9:615-629

Somasekhara YM (1999) New record of Ceratocystis fimbriata causing wilt of pomegranate in India. Plant Dis 83:400

Steimel J, Engelbrecht CJB, Harrington TC (2004) Development and characterization of microsatellite markers for the fungus Ceratocystis fimbriata. Mol Ecol Notes 4:215218 
Tamura K, Peterson D, Peterson N, Stecher G, Nei M, Kumar S (2011) MEGA5: Molecular Evolutionary Genetics Analysis Using Maximum Likelihood, Evolutionary Distance, and Maximum Parsimony Methods. Mol Biol Evol 28:2731-2739

Tarigan M, Roux J, Van Wyk M, Tjahjono B, Wingfield MJ (2011) A new wilt and die-back disease of Acacia mangium associated with Ceratocystis manginecans and $C$. acaciivora sp. nov. in Indonesia. S Afr J Bot 77:292-304

Van Wyk M, Al Adawi AO, Khan IA, Deadman ML, Al Jahwari AA, Wingfield BD, Ploetz R, Wingfield MJ (2007) Ceratocystis manginecans sp. nov., causal agent of a destructive mango wilt disease in Oman and Pakistan. Fungal Divers 27:213-230

Van Wyk M, Wingfield BD, Mohali S, Wingfield MJ (2009) Ceratocystis fimbriatomima, a new species in the $C$. fimbriata sensu lato complex isolated from Eucalyptus trees in Venezuela. Fungal Divers 34:175-185

Van Wyk M, Wingfield B, Marin M, Wingfield M (2010) New Ceratocystis species infecting coffee, cacao, citrus and native trees in Colombia. Fungal Divers 40:103-117

Van Wyk M, Wingfield BD, Al-Adawi AO, Rossetto CJ, Ito MF, Wingfield MJ (2011) Two new Ceratocystis species associated with mango disease in Brazil. Mycotaxon $117: 381-404$

Van Wyk M, Wingfield BD, Wingfield MJ (2013) Ceratocystis species in the Ceratocystis fimbriata complex. In: Seifert KA, de Beer W, Wingfield MJ (eds) Ophiostomatoid fungi: expanding frontiers. Utrecht, the Netherlands: Biodiversity Series 12:65-73

Viegas AP (1960) Seca da mangueira (Mango Wilt). Bragantia 19:163-182

Vos P, Hogers R, et al. (1995) AFLP: a new technique for DNA fingerprinting. Nucleic Acids Res 23:4407-4414

Webster RK, Butler EE (1967a) A morphological and biological concept of the species Ceratocystis fimbriata. Can J Bot 45:1457-1467 
Webster RK, Butler EE (1967b) The origin of self-sterile, cross-fertile strains and culture sterility in Ceratocystis fimbriata. Mycologia 59:212-221

Wingfield MJ, Beer Cd, Visser C, Wingfield BD (1996) A new Ceratocystis species defined using morphological and ribosomal DNA sequence comparisons. Syst Appl Microbiol 19:191-202

Witthuhn RC, Harrington TC, Steimel JP, Wingfield BD, Wingfield MJ (2000) Comparison of isozymes, rDNA spacer regions and MAT-2 DNA sequences as phylogenetic characters in the analysis of the Ceratocystis coerulescens complex. Mycologia $92: 447-452$

Wood SL (1982) The bark and ambrosia beetles of North and Central America (Coleoptera: Scolytidae), a taxonomic monograph. Great Basin Naturalist, Memoirs 6:1-1356 